\title{
What Can Happen to Public Relations Who Behave Unethically?
}

\author{
Matilda Kolić Stanić \\ Catholic University of Croatia, Croatia
}

\section{Abstract}

Ethics has become professional imperative in public relations field, whereby unethical action is not any more considered as integral characteristic of public relations (PR) professionals, especially among scholars and practitioners. However, the question what if public relations professionals really violate ethical standards did not disappear, and concerns every instance linked to the PR-sector. In other words, the question is what disciplinary measures can be taken against the member of PR-associations. This study, based on a qualitative content analysis of websites and statutes of 20 national and international public relations associations from Europe and the US, shows what mechanisms exist in the associations to sanction the unethical behaving of their members. The analysis showed that, unlike international associations that do not take disciplinary action, although the majority of associations has bodies that could provide disciplinary measures (which includes expulsion from membership), only four associations give clear instructions how to make complaints if unethical behaving is detected, and, furthermore, only three associations indicate the consequences of unethical action by publishing judgments on a regular basis. Although the ethics is recognized as crucial principle at declarative level among all associations, efforts of some associations to establish disciplinary committees and to provide real sanctions of unethical professional behavior, can be considered as a progress in defining public relations as a profession with high ethical standards.

Keywords: public relations, ethics, sanctions, communication, associations, violation of codes

JEL classification: M14, D8

\section{Introduction}

The ethics and public relations, no matter how sometimes their co-existence may seem to be considered as an oxymoron - especially from a historical perspective - has nowadays become more than inseparable: ethics has become PR's professional imperative (e.g. Grunig, 2014; Verčič et al., 1996; Ole.dzki, 2011; Tsetsura et al., 2016; Huang, 2001). Public relations is undoubtedly a growing communications sector deeply involved in functioning of corporate, cultural, political, non-profit, nongovernmental and other organizations, so it is not surprise that the interests for understanding that relative young profession may cross the border of public relations sector.

So far, numerous studies have been published on the importance of ethical behaving by public relations professionals (e. g., Ki et al., 2010; Tsetsura et al., 2016; Bowen et al., 2016), and it could be said that there is a consensus among theorists and professionals that, except professional criteria, the profession is also validated by its ethical level. In other words, public relations ethics has gained strategic importance for the profession which articulates itself especially through associations of PRprofessionals (e. g., Yang et al, 2014; Kolić Stanić 2018b; 2018c). 
Ethical conduct is closely linked to the positioning of every profession in the field, and important role in that mission play associations. Noordegraaf (2011), except cognitive and symbolic mechanisms by which the profession defines itself, emphasizes also the normative mechanism, which includes, among other issues, codes of conducts, sanctions, and disciplines. Responsibility in making the ethical mechanism useful in public relations field lies on associations whose task is to monitor ethical behavior among members (Tsetsura et al., 2016).

Public relations associations strongly emphasize their ethical goals but, to put it bluntly, what is said does not mean it is done: while most associations declare ethics as crucial issue, they does not promote it with the same intensity, and much less operationalize it by for example, publishing names and the cases of ethics violations (Kolić Stanić, 2018c). Problematic is, also, that young profession of public relations and its practitioners in many countries are not statutory protected, and their acting is not always recognized by state laws, what suggests that the codes of ethics are not supported by legislative solutions "and therefore it has not been possible to guarantee that practitioners adhere to codes of ethics" (Skinner et al., 2003, p. 20).

Nevertheless, in addition to the laws and regulations to which public relations professionals are obligated in some countries (O'Connor et al., 2004), and in addition to the internal codes of the organizations in which they are employed, their professional work is governed by the codes of ethics adopted by public relations associations at national and international levels. But this does not, of course, mean that the public relations profession and its practitioners have become indisputably ethical, especially if codes in itself are not clear in defining ethical behaving (Kolic Stanić, 2019), but rather that they would declaratively wish to act ethically (Kolic Stanić, 2018c).

This raises the important question of the effectiveness of sanctioning "offenders" in public relations. As, for example, evidenced by the study of the presence of codes of conduct in 1,562 public relations agencies in the US, none of them sanctions the unethical conduct of their employees (Ki et al., 2010). Special attention among scholars was also paid to the PRSA - the largest association of public relations professionals in the United States, which code of ethics was under historical debate should it "show teeth" or not. Namely, it has been shown that in the 50 years of the association's history, the Ethics Committee has investigated 231 cases of breaches of the code of ethics, and only 11 members have been sanctioned during this entire period (Fitzpatrick, 2002a; 2002b). On the other hand, in its short history, the German DRPR (40 years younger than PRSA) has already been recognized as effective in sanctioning, gaining also by that more respect (Avenarius, 2007).

An important question is often left unanswered in the literature: What happens if a PR-practitioner breaks a code that binds him or her as a member of a PR association? The question could be also articulated as follows: How do public relations associations handle their accused "offenders" through their disciplinary procedure? This can also be considered as the main research question of this paper. The further research questions are: What kind of ethical boards are present among associations; What kind of sanctions associations might apply to the offenders; How clear is the operationalization of complaints? However, it is also worthwhile to find out if there are differences in disciplinary procedures with regard to the type (of membership) of organizations and geographical position (US - European Union).

In order to answer these questions, the research included 20 public relations associations at national and international levels in the European Union and the United States. The main goal is to find out how associations conduct disciplinary proceedings 
against their "offending members" by using the method of qualitative content analysis of websites and statutes of associations.

The paper is structured in the next way: after clarifying the methodology of the study, the results briefly outline the disciplinary measures and procedures for each association in the sample. The discussion answers research questions and the conclusion bring evidences for the debate on the importance of discipline measures for members of associations who break a code.

\section{Methodology}

The research was conducted using the qualitative content analysis method (Krippendorff, 1980) on the sample of 18 public relations associations: 18 national and 2 international (Table 1). Associations from the following countries are included, since the criterion was to choose countries with democratic governance and to be sure that the researcher is familiar with a language of published materials: Austria (4), Croatia (1), Germany (5), Italy (2), Spain (2), United Kingdom (2) - all European Union countries; and the United States (2). It is important to notice that the sample included under the term "associations" also 2 national committees, Austrian PR-Ethik Rat and German DRPR. Although they are not associations with membership, the reason to put it in the sample lies in the fact that the members of all national associations from those countries are subordinated to both committees in the matter of ethics.

The research took into consideration that almost in every selected country there exist association for individual members and another one for corporate members, mainly agencies, or associations with mixed membership. Therefore, the sample was created to engage as much as more members, to be sure to "cover" the majority of professionals and agencies involved in national fields. Two international associations the Global Alliance for Public Relations and Communication Management - GA, and the International Communications Consultancy Organization - ICCO were taken in the sample, since the majority of national associations are referring to two of them.

Table 1

The Sample

\begin{tabular}{llll}
\hline Association & Country & Full Name of Association & $\begin{array}{l}\text { Type of } \\
\text { Membership }\end{array}$ \\
\hline $\begin{array}{l}\text { PR- ETHIK- RAT } \\
\text { Www.prethikrat.at }\end{array}$ & Austria & $\begin{array}{l}\text { Austrian Public Relations Ethics Council } \\
\text { (Österreichische Ethik-Rat für Public Relations) }\end{array}$ & Individual \\
$\begin{array}{l}\text { PRVA } \\
\text { Prva.at }\end{array}$ & Austria & $\begin{array}{l}\text { Public Relations Association Austria (Public } \\
\text { Relations Verband Austria) }\end{array}$ & Mixed \\
$\begin{array}{l}\text { ViKOM } \\
\text { Www.vikom.at }\end{array}$ & Austria & $\begin{array}{l}\text { Association for Integrated Communication } \\
\text { (Verband für integrierte Kommunikation) }\end{array}$ & Mixed \\
$\begin{array}{l}\text { ÖPR } \\
\text { Www.prguetezeichen.at }\end{array}$ & Austria & $\begin{array}{l}\text { Austrian PR Quality Seal (Österreichisches PR- } \\
\text { Gütezeichen) }\end{array}$ & Mixed \\
$\begin{array}{l}\text { CPRA } \\
\text { Www.huoj.hr }\end{array}$ & Croatia & $\begin{array}{l}\text { Croatian Public Relations Association (Hrvatska } \\
\text { udruga za odnose s javnošć) }\end{array}$ & Individual \\
$\begin{array}{l}\text { DRPR } \\
\text { drpr-online.de }\end{array}$ & Germany & $\begin{array}{l}\text { German PR Council (Deutscher Rat für Public } \\
\text { Relations) }\end{array}$ & Individual \\
$\begin{array}{l}\text { DPRG } \\
\text { dprg-online.de }\end{array}$ & Germany & $\begin{array}{l}\text { German Public Relations Society (Deutsche } \\
\text { Public Relations Gesellschaft) }\end{array}$ & Mixed \\
\hline
\end{tabular}




\begin{tabular}{|c|c|c|c|}
\hline $\begin{array}{l}\text { BdP } \\
\text { www.bdp-net.de }\end{array}$ & Germany & $\begin{array}{l}\text { German Federal Association of Spokespersons } \\
\text { (Bundesverband deutscher Pressesprecher) }\end{array}$ & Mixed \\
\hline $\begin{array}{l}\text { GPRA } \\
\text { www.gpra.de }\end{array}$ & Germany & $\begin{array}{l}\text { Society of Public Relations Agencies } \\
\text { (Gesellschaft Public Relations Agenturen) }\end{array}$ & $\begin{array}{l}\text { Corporative } \\
\text { membership }\end{array}$ \\
\hline $\begin{array}{l}\text { DeGePol } \\
\text { www.degepol.de }\end{array}$ & Germany & $\begin{array}{l}\text { German Association of Political Consultants } \\
\text { (Deutsche Gesellschaft für Politikberatung) }\end{array}$ & Mixed \\
\hline $\begin{array}{l}\text { FERPI } \\
\text { www.ferpi.it }\end{array}$ & Italy & $\begin{array}{l}\text { Italian Public Relations Federation (Federazione } \\
\text { Relazioni Pubbliche Italiana) }\end{array}$ & Individual \\
\hline $\begin{array}{l}\text { ASSOREL } \\
\text { WwW.assorel.it }\end{array}$ & Italy & $\begin{array}{l}\text { Association of Communication and Public } \\
\text { Relations companies (Associazione imprese di } \\
\text { comunicazione e relazioni pubbliche) }\end{array}$ & $\begin{array}{l}\text { Corporative } \\
\text { membership }\end{array}$ \\
\hline $\begin{array}{l}\text { PRCA } \\
\text { www.prca.org.uk }\end{array}$ & UK & Public Relations Consultants Association & Mixed \\
\hline $\begin{array}{l}\text { CIPR } \\
\text { www.cipr.co.uk }\end{array}$ & UK & Chartered Institute of Public Relations & Mixed \\
\hline $\begin{array}{l}\text { DIRCOM } \\
\text { www.dircom.org }\end{array}$ & Spain & $\begin{array}{l}\text { Association of Communication Managers } \\
\text { (Asociación de Directivos de Comunicación) }\end{array}$ & Individual \\
\hline $\begin{array}{l}\text { ADECEC } \\
\text { www.adecec.com }\end{array}$ & Spain & $\begin{array}{l}\text { Association of Communication and Public } \\
\text { Relations Consultancy Companies (Asociación } \\
\text { de Empresas Consultoras en Relaciones } \\
\text { Públicas y Comunicación) }\end{array}$ & $\begin{array}{l}\text { Corporative } \\
\text { membership }\end{array}$ \\
\hline $\begin{array}{l}\text { PRSA } \\
\text { www.prsa.org }\end{array}$ & USA & Public Relations Society of America & Individual \\
\hline $\begin{array}{l}\text { PR COUNCIL } \\
\text { prcouncil.net }\end{array}$ & USA & Public Relations Council & $\begin{array}{l}\text { Corporative } \\
\text { membership }\end{array}$ \\
\hline $\begin{array}{l}\text { GA } \\
\text { www.globalalliancepr.or } \\
\text { g }\end{array}$ & $\begin{array}{l}\text { Internatio } \\
\text { nal }\end{array}$ & $\begin{array}{l}\text { Global Alliance for Public Relations and } \\
\text { Communication Management }\end{array}$ & $\begin{array}{l}\text { Corporative } \\
\text { membership } \\
\text { (associations+in } \\
\text { stitutions) }\end{array}$ \\
\hline $\begin{array}{l}\text { ICCO } \\
\text { iccopr.com }\end{array}$ & $\begin{array}{l}\text { Internatio } \\
\text { nal }\end{array}$ & $\begin{array}{l}\text { International Communications Consultancy } \\
\text { Organization }\end{array}$ & $\begin{array}{l}\text { Corporative } \\
\text { membership } \\
\text { (associations+a } \\
\text { gencies) }\end{array}$ \\
\hline
\end{tabular}

Source: Authors' work

The matrix for analyzing "disciplinary role of the associations" (Kolić Stanić, 2018a) was divided into two main categories: the first is the existence of ethical bodies or other bodies that hold the power to carry out disciplinary procedures according to the statute or some other basic document, and second is the existence of disciplinary measures. For the purpose of this research, which tries to find how associations presents its ethical procedures to the publics, there was no necessary to make indepth analysis of the organs and disciplinary procedures of the associations, or analysis of all the references that can be found on these issues, since that could have move the research in the field of legal sciences. Instead, the intention is to trace main bodies of the associations and its measures to be able to conclude how associations fulfill its disciplinary role.

The research was focused only at materials published at associations websites (statutes and other content that represents associations' treatment of discipline measures), finally till July 2017. 


\section{Results}

The research results will be displayed according to the subcategories in the matrix. It will first show whether some kind of ethics committees/boards exist in associations, and then comes the analysis/examples how major committees in associations perform the function of ethics committees. The next subcategory is an indication of what disciplinary measures can be exercised over members of associations. The last subcategory concerns the possibility of submitting complaints on unethical behaving of associations members, and publishing the decisions on violating ethical norms. (Table 2)

Table 2

Overview of Ethical Bodies and Measures Across the PR-Associations

\begin{tabular}{|c|c|c|c|c|c|c|}
\hline Association & $\begin{array}{l}\text { Ethical } \\
\text { Board }\end{array}$ & $\begin{array}{l}\text { Ethical } \\
\text { function } \\
\text { of Main } \\
\text { Board }\end{array}$ & Sanctions & $\begin{array}{l}\text { Instructions for } \\
\text { reporting } \\
\text { misconducts }\end{array}$ & $\begin{array}{l}\text { Publishing } \\
\text { the } \\
\text { decisions }\end{array}$ & $\begin{array}{l}\text { Decisions } \\
\text { not just for } \\
\text { members }\end{array}$ \\
\hline $\begin{array}{l}\text { PR-ETHIK- } \\
\text { RAT }\end{array}$ & + & + & + & + & + & + \\
\hline PRVA & + & + & + & - & - & - \\
\hline ViKOM & - & + & + & - & - & - \\
\hline ÖPR* & - & - & - & - & - & - \\
\hline CPRA & + & + & + & - & - & + \\
\hline DRPR & + & + & + & + & + & + \\
\hline DPRG & + & - & - & - & - & - \\
\hline $\mathrm{BdP}$ & - & + & + & - & - & - \\
\hline GPRA & ? & ? & ? & ? & ? & ? \\
\hline DeGePol & - & + & + & - & - & - \\
\hline FERPI & + & - & + & - & - & - \\
\hline ASSOREL & + & + & + & - & - & - \\
\hline PRCA & + & + & + & + & - & - \\
\hline CIPR & + & + & + & + & + & - \\
\hline Dircom & - & + & + & - & - & - \\
\hline ADECEC & - & + & + & - & - & - \\
\hline PRSA & + & + & + & - & - & - \\
\hline PR-Council & ? & $?$ & ? & ? & ? & ? \\
\hline GA & - & + & + & - & - & - \\
\hline ICCO & - & + & + & - & - & - \\
\hline
\end{tabular}




\section{Ethical Boards and Courts of Honors}

The first intention of the research was to detect if associations have ethical bodies, often called "ethical boards", or if they have some other similar formal instances that are responsible to carry out disciplinary procedures according to the associations' bylaws. The research has shown that 10 (the half) of the associations included in the sample have pointed - either at their statutes, either at other places at their web - that they have ethical boards. But if we take into consideration that 2 from the total of analyzed associations actually exist as ethical boards at national levels - Austrian PREthik-Rat and German DRPR - than the finding is that 8 of 18 analyzed associations have presented its official ethical board - what is less than a half.

Since both national ethical councils from Austria and Germany share similar profile, it is maybe enough to note on the example of PR-Ethik Rat that their task is to activate the control procedure after complaints. The board has presented clear competences, clear ethical principles and clear modus operandi in procedures for complaints. It is interesting to note that both boards act independently of the supporting associations and that their activities are not limited just to the members of organizations, but also refer to all those practitioners involved in public communication. Only the Croatian CPRA is noting the similar thing, concerning PRpractitioners engaged in its national field.

Two associations from United Kingdom have presented their boards in a very extensive way. PRCA has the Professional Practices Committee whose task is to promptly investigate any complaint properly brought before them against a member under the Association's Complaints and Arbitration Procedure or the Memorandum and Articles of Association. CIPR has also the Professional Practices Committee who convenes a hearing led by the members of the Committee for professional practices. The procedure involves lawyers together with the Regulatory Consultant and CIPR's solicitor. CIPR's statute mentions that four bodies and/or persons intervene in the disciplinary process: Professional Standards Panel, Appeals Panel, Arbiter and Regulatory Consultant.

Croatian CPRA has the Court of Honor who decides on disciplinary proceedings against members and can, as mentioned, also give an opinion on the dishonorable behavior of professionals who are not members of the association. German DPRG has also Honorary Council whose mission is to protect the professional reputation of each member, but also to identify and sanction all violations of the principles and interests of the DPRG.

Italian FERPI and Assorel both have the bodies for discipline: the Board of probi viri. FERPI's task is to ensure that the members observe the established codes, but it also provides interpretations of the statute, expressing advisory opinions, intervening in disputes between shareholders, expressing opinions on professional fees.

Assorel's board consists of three persons charged to judge ethical and professional behavior of the associated company which is deemed to violates the interests of the Association or of one or more associated companies. The Austrian PRVA also has an arbitration court (Schiedsgericht) which can rather be considered as conciliation body.

\section{Ethical Functions of Main Boards}

The second subcategory in the research concerns the ethical role of major boards in associations. In 15 associations, central committees are charged with imposing sanctions on members who violate ethical and other norms. But with the exception of the Austrian PR-Ethik Rat and the German DRPR, which are councils independent to other instances, and except for two associations for which data were not available, 
only Italian FERPI did not point that responsibility for sanctioning unethical behaving of its members lies on the main board of the association.

The majority of analyzed associations' function - at least at declarative level - in the way that ethical boards just suggest the sanctions and the main boards are instances to make decisions that can shape "the fate" of unethical members. For example, German BdP in its statute explains that it is planed that a member may be expelled for a serious violation of the German communication code and in that case it is the Governing Council that proceeds with the expulsion. Or, another example, British CIPR Council with its 28 members approves the decision after the procedure provided by Committee for professional practices.

But sometimes it is not so simple to make clear line between ethical board and main committee of associations. For example, the ethical board of probi viri of Italian Assorel operates at the request of either the president or the Governing Council or the General Assembly, unlike the Ethical Councils in Germany and Austria, which also act on requests from an area outside the association. It can also be noted that Spanish Dircom's Governing Council plays a role of representation, and therefore of responsibility, not only before physical or legal persons, but also before courts and tribunals in all cases in which it is necessary to issue statements or deal with complaints.

\section{Sanctions and other discipline measures}

The third subcategory is actually answering the question what can happen to the member who violates the codes linked to particular association. But before mentioning the sanctions and other measures, it is necessary to present what is according to associations considered as unethically behavior.

Except the fact that every action which is against the codes of ethics can be treated as unethical acting, what is mentioned among majority of associations from the sample, in the category of unethical behavior can be put also, for example, dishonorable acting (PRVA, ViKOM), or failure to comply with the decisions of the association (CPRA), or, similarly, violations of the principles and interests of the association (DPRG), or violate quality criteria (DeGePol). Furthermore, sanctions can be verdict by violating of any rule concerning the exercise of professional public relations activities (FERPI), or activities contrary to the philosophy and spirit of the association (DIRCOM), or, as the final example, under the sanctions can come any violation of the social objectives of the association, but also the antisocial behavior (ADECEC).

The research found that 16 of 20 associations highlight the possibility of expulsion, which is also the most frequently mentioned measure. But the analysis showed that the associations that explicitly state other types of sanctions, apart from the expulsion measure, are in the minority. The Austrian PR-Ethik Rat announces that three solutions are possible: the complaint, a warning in cases less serious, or the declaration that there was no violation. CPRA among disciplinary proceedings mentions first warning, second warning, expulsion for one year or permanent expulsion. FERPI's measures are recall, censorship, suspension or cancellation from the membership; and PRCA warns, admonishes, reprimands, suspends or terminates the membership of unethical members. It is interesting to note that Italian Assorel has some kind of pre-sanctions, since the companies whose leaders are interdicted, bankrupt or subject of penal condemnation for which they have not obtained rehabilitation - are not admitted to the association. The same decision is for those who have been affected by disciplinary measures contemplated by the national or international codes of professional ethics. Sanctions against associated companies are, for example, suspensions or the initiation of a verification procedure. 
Very comprehensive explanation of sanctions and discipline measures comes from British CIPR. Except of reproaches, severe reproaches, expulsion, removal from the Institute, removal and suspension of any right or privilege enjoyed by the members, it mentions also the procedural costs - on the charge of sanctioned members. Even more, in the case that the member of the association done his job against professional standards, the client can request him to return the sum received for the service.

\section{Submitting Complaints and Publishing the "Verdicts"}

An attempt to answer the question how serious are the associations in their commitment to charge the offenders of ethical and other rules the research aimed to find out is there any concrete possibility of submitting complaints on unethical behaving of associations members, and if there exist the outcome of the action in publishing the decisions on violating ethical norms.

Only 4 associations give a kind of tutorial how to make complaints. The Austrian PREthik Rat and German DRPR offer the possibility for every person or organization to report misconduct in the field of public relations. They have address of the contact for complaints, and even have at their web-sites the form to fill out to submit a complaint. Another two comes from United Kingdom: PRCA notes in its statute as well as on the web-site that every complaint against a member must be submitted in writing addressed to the Secretary, and similarly CIPR explains that the complaint can be forwarded to a concrete contact by anyone who believes that a CIPR member has violated the code.

Actually, the same group of associations is dedicated to the mission to finish the circle (submitting the complaints - process - making decision on sanctions) by publishing "verdicts". PR-Ethik Rat and DRPR publish at the official website of the institutions the outcome of the complaints processes, and the same is with British CIPR. On the other hand, PRCA has a milder version by hypothetically stating that warnings can be published "if the Governing Council deems it appropriate", therefore it cannot be considered that it publishes decision on a regular bases.

\section{Discussion}

The results of this study and the general conclusions should be approached with the caution as it has quite clear limitations. There may be a big gap between the declaratory statements contained in the statutes and websites of the PR-associations and the actual state of their implementation, since the research only considered what was published. In other words, a fence should be put in place, because if the web site does not publish "verdicts" on the committer of unethical acts, this does not necessarily mean that they may not have been pronounced at internal level. At the same time, while this may be the downside to research, the relevance to the results can be justified by the attitude that web considers to be the first PR's mass medium (White et al., 1999).

In order to answer the question of how do public relations associations handle their accused "offenders" through their disciplinary procedures, it was first necessary to consider what kind of ethical boards are present among the associations. Although ethics plays strategical role in defining nowadays PR-profession, it is somewhat surprising that the majority of associations from the sample do not have specifically designated ethics committees that would be tasked with evaluating instances of unethical treatment among members. Likewise, for the vast majority of associations, ethics committees could be more considered as advisory bodies to major committees, charged with imposing disciplinary measures. The exceptions are, so to 
speak, supreme-bodies for national territories in Austria and Germany PR-Ethik Rat and DRPR, which are guaranteed independence in action.

The study also noted a disparity between stating what associations consider unethical treatment (e. g., from code violations to "antisocial behavior") and the types of sanctions that can be taken. Although the majority of associations (16 out of 20) mention the possibility of expulsion from membership, there are minority associations that list several different degrees of punishment. Perhaps the most specific in this regard is the British CIPR, whose provision that the "offender" must return the honorarium he has received for an unethical or unprofessional engagement in the project may even be considered a financial penalty.

Probably the largest disparity between the analyzed associations emerged when the research stepped into the implementation of disciplinary measures, that is, the publication of "judgments". Of the 20 associations, only 3 declare or announce the outcomes of disciplinary actions, what indicates the effectiveness of ethical goals declared by associations.

The results from this study can draw some conclusions even if one looks at geographical differences. The fact that the Austrian and German PR-Ethik Rat and DRPR, and the British CIPRA announce the outcomes of ethical processes - but also with regard to some other results - shows that declarative and operational levels of ethical conduct have moved closer to one another among European Union associations more than in US.

Some results may also be significant given the type of membership. Two international public relations associations - GA and ICCO - do not take ethical sanctions against their members. This could also be explained by the fact that they do not rely on individual national legislations (because they are international associations). But it should also be noted that both international associations have no individual membership, and research has shown that national associations with individual and mixed membership have stronger ethical mechanisms in comparison to associations with corporative membership.

\section{Conclusion}

The analysis of statutes (or other basic documents) of PR-associations showed that the majority of associations has an ethical body or another body that performs the tasks related to the discipline of its members and all analyzed documents deal with some kind of disciplinary measures. But there is also a disparity between the extensive declarative level in listing ethical demands on membership of PR-associations, and the much deficient mechanisms of dealing with potential unethical action among members.

Although they are in the minority in relation to the sample, there exist encouraging examples of associations that have demonstrated ethics as a lasting public relations strategy, at declarative and operational levels. Certainly, important results and explanations of the current situation would be obtained using research methods such as interviews with members of general boards and with members of ethics committees at PR-associations.

Every association from the sample adopts an ethical code, but without high level of independence of disciplinary committee and real sanctions in the face of unethical professional behavior, the codes and associations have lower coercive value and therefore, beyond the declarations of principle, comes into question how they really can benefit either the profession or the society. This research showed that there exist few associations which proved that unethical professional behaving among professionals has to come under proper sanctions. It is a step toward social responsible 
self-regulation, which can have an effects also on the other sectors to which the public relation professionals are linked to.

\section{References}

1. Avenarius, H. (2007), "German experiences with codes and their enforcement", Journal of Communication Management Vol. 11, No. 2, pp. 99-116.

2. Bowen, S. A., Hung-Baesecke, C.-J. F., Chen, Y.-R. R. (2016), "Ethics as a precursor to organization-public relationships: Building trust before and during the OPR model", Cogent Social Sciences, Vol. 2, No. 1.

3. Fitzpatrick, K. R. (2002a), "Evolving Standards in Public Relations: A Historical Examination of PRSA's Codes of Ethics", Journal of Mass Media Ethics, Vol. 17, No. 2, pp. 89-110.

4. Fitzpatrick, K. R. (2002b), "From Enforcement to Education: The Development of PRSA's Member Code of Ethics 2000", Journal of Mass Media Ethics, Vol. 17, No. 2, pp. 111-135.

5. Grunig, J. E. (2014), "Ethics problems and theories in public relations", Communiquer, Vol. 11, pp. 1-14, available at: http://journals.openedition.org/communiquer/559 (3 April 2019).

6. Huang, Y. H. (2001), "Should A Public Relations Code of Ethics Be Enforced?", Journal of Business Ethics, Vol 31, No. 3, pp, 259-270.

7. Ki, E. J., Kim, S. Y. (2010), "Ethics Statements of Public Relations Firms: What Do They Say?", Journal of Business Ethics, Vol. 91, No. 2, pp. 223-236.

8. Kolić Stanić, M. (2018a) "Criteri fondamentali delle relazioni pubbliche nei codici di etica. Un confronto con i criteri etici del giornalismo secondo Luka Brajnovic" ("Fundamental criteria of public relations in codes of ethics. A comparison with the ethical criteria of journalism according to Luka Brajnović"), Dissertation, Rome, Pontifical University of the Holy Cross, pp. 186-194.

9. Kolić Stanić, M. (2018b), "Education as the Essential Part of Public Relations Ethics Codes", in the Proceedings of the 4th ENTerprise REsearch InNOVAtion Conference, Split, Croatia, Udruga za promicanje inovacija i istraživanja u ekonomiji "IRENET", pp. 98104.

10. Kolić Stanić, M. (2018c), "Ethics as the Strategy for Public Relations Associations", in the Proceedings of the 4th ENTerprise REsearch InNOVAtion Conference, Split, Croatia, Udruga za promicanje inovacija i istraživanja u ekonomiji "IRENET", pp. 120-126.

11. Kolić Stanić, M. (2019), "Transparency in Public Relations: Evidence from Associations' Ethics Codes", Interdisciplinary Description of Complex Systems, Vol. 17, No. 2-B, pp. 417-429.

12. Krippendorff, K. (1980), Content Analysis: An Introduction to its Methodology, Sage Publications, Newbury Park.

13. Noordegraaf, M. (2011), "Remaking professionals? How associations and professional education connect professionalism and organizations", Current Sociology, Vol. 59, No. 4, pp. $465-488$.

14. O'Connor, N., Falconi, T. M. (2004), "Profiling the regulatory environment of public relations practice in the UK, Italy and South Africa", Journal of Communication Management, Vol. 9, No. 1, pp. 28-55.

15. Olecdzki, J. (2011), "Public relations without ethics will face the same fate as propaganda. Research reflections. (Case study of PR associations in Poland)", Central European Journal of Communication, Vol. 4, No. 6, pp. 141-155.

16. Skinner, C., Mersham, G., Valin, J. (2003), "Global protocol on ethics in public relations", Journal of Communication Management, Vol. 8, No. 1, pp. 13-28.

17. Tsetsura, K., Valentini, Ch. (2016), "The 'Holy' Triad in Media Ethics: A Conceptual Model for Understanding Global Media Ethics", Public Relations Review, Vol. 42, No. 4, pp. 573581.

18. Verčič, D., Grunig, L. A., Grunig, J. E. (1996), "Global and specific principles of public relations: Evidence from Slovenia", in Culbertson, H. M., Chen, N. (Eds.), International public relations: A comparative analysis, Lawrence Erlbaum Associates, Mahwah, NJ, pp. 31-65. 
19. Yang, A., Taylor, M. (2014), "A Global Perspective on Public Relations Professionalism: Mapping the Structure of Public Relations Associations' International Networks", Journalism \& Mass Communication Quarterly, Vol. 91, No. 3, pp. 508-529.

20. White, C., Raman, N. (1999), "The World Wide Web as a Public Relations Medium: The Use of Research, Planning, and Evaluation in Web Site Development," Public Relations Review, Vol. 25, No. 4, pp. 405-419.

\section{APPENDIX}

BASIC DOCUMENTS AND STATUTES OF PUBLIC RELATIONS ASSOCIATIONS

1. Asociación de Directivos de Comunicación (Dircom), "Estatutos", available at: http://www.dircom.org/images/Estatutos-Dircom-10-06-2015.pdf (21 March 2017),

2. Asociación de Empresas Consultoras en Relaciones Públicas y Comunicación (ADECEC), "Estatutos", available at: http://www.adecec.com/quienes_somos/estatutos.php (22 March 2017).

3. Associazione imprese di comunicazione e relazioni pubbliche (Assorel), "Statuto", available at: https://www.assorel.it/relazioni-pubbliche/files/download_file_73.pdf

(20 March 2017).

4. Bundesverband deutscher Pressesprecher (BdP), "Satzung", available at: https://www.bdp-net.de/mitgliedschaft/satzung (6 March 2017).

5. Chartered Institute of Public Relations (CIPR), "By-Laws Of The Chartered Institute Of Public Relations", available at: https://www.cipr.co.uk/sites/default/files/Bylaws\%20\%282017\%29.pdf (29 March 2017).

6. Deutsche Gesellschaft für Politikberatung (DeGePol), "Satzung", available at: http://www.degepol.de/satzung (7 March 2017).

7. Deutsche Public Relations Gesellschaft (DPRG), "Satzung der Deutschen Public Relations Gesellschaft e.V.", available at:

http://dprg-online.de/wp-content/uploads/2016/08/DPRG-Satzung- Ausdruck.pdf (3 March 2017).

8. Deutscher Rat für Public Relations (DRPR), "Beschwerdeordnung DRPR Deutscher rat für Public Relations", available at:

http://drpr-online.de/wp-content/uploads/2015/05/DRPR- BESCHWERDEORDNUNG052015.pdf (3 March 2017).

9. Federazione Relazioni Pubbliche Italiana (FERPI), "Statuto", available at: http://www.ferpi.it/associazione/statuto-regolamento-e-codici/statuto/

(17 March 2017).

10. Gesellschaft Public Relations Agenturen (GPRA), available at: www.gpra.de (17 March 2017).

11. Global Alliance for Public Relations and Communication Management (GA), "By- laws of the Global Alliance for Public Relations and Communication Management", available at:

https://static l.squarespace.com/static/

$561 \mathrm{~d} 0274 \mathrm{e} 4 \mathrm{~b} 0601 \mathrm{~b} 7 \mathrm{c} 814 \mathrm{ca} / \mathrm{t} / 56 \mathrm{~d} 045767 \mathrm{c} 65 \mathrm{e} 4 \mathrm{~d} 6 \mathrm{eac} 880 \mathrm{ea} / 1456489851498 / \mathrm{GA}-$

bylaws-Switzerland-June-2013+\%281\%29.pdf (6 July 2017).

12. Hrvatska udruga za odnose s javnošću (HUOJ), "Statut Hrvatske udruge za odnose s javnošću", available at:

http://www.huoj.hr/files/File/HUOJdokumenti/Statut\%20Hrvatske\%20udruge \%20za\%20odnose\%20s\%20javnoscu\%207.7.2015..pdf (15 March 2017).

13. International Communications Consultancy Organization (ICCO), "The ICCO Bylaws", available at: https://iccopr.com/wp-content/uploads/2017/05/The-ICCO-Bylaws-.pdf (1 July 2017).

14. Österreichische Ethik-Rat für Public Relations (PR- ETHIK- RAT), "Geschäftsordnung des Österreichischen Ethik-Rats für Public Relations", available at: http://www.prethikrat.at/pr-ethik-rat/geschaeftsverordnung/ (1 March 2017). 
15. Österreichisches PR-Gütezeichen (ÖPR), available at: www.prguetezeichen.at (1 March 2017).

16. Public Relations Consultants Association (PRCA), "PRCA Memorandum and Articles of Association", available at:

http://www.prca.org.uk/about-us/pr-standards/professional-charter-and-codesconduct (24 March 2017).

17. Public Relations Council (PR COUNCIL), available at: prcouncil.net (24 March 2017).

18. Public Relations Society of America (PRSA), "Public Relations Society Of America Bylaws", available at:

http://www.prsa.org/wp-content/uploads/2017/02/PRSA_Bylaws.pdf (30 March 2017).

19. Public Relations Verband Austria (PRVA), "Verbansstatuten", available at: http://prva.at/itrfile/_1_/421cd839c3335821976a46dab3dd0f4d/Statuten.pdf (1 March 2017).

20. Verband für integrierte Kommunikation (ViKOM), "Statuten", available at: http://www.vikom.at/der-vikom/statuten/ (1 March 2017).

\section{About the author}

Matilda Kolić Stanić, Ph.D. graduated at the Pontifical University of the Holy Cross in Rome, where she got her PhD with the topic "Fundamental criteria of public relations in codes of ethics. A comparison with the ethical criteria of journalism according to Luka Brajnović". Her research interests are public relations, media relations, ethics and communication. She participated in the projects "Family and Media" and "Science communication: the role of scientific community and curriculum development" during her position as a research assistant at the University Department of Croatian Studies, University of Zagreb. She is engaged as a lecturer at Catholic University of Croatia. The author can be contacted at kolicstanicmatilda@gmail.com. 